Russian Academy of Sciences, Far Eastern Branch

Botanical Garden-Institute

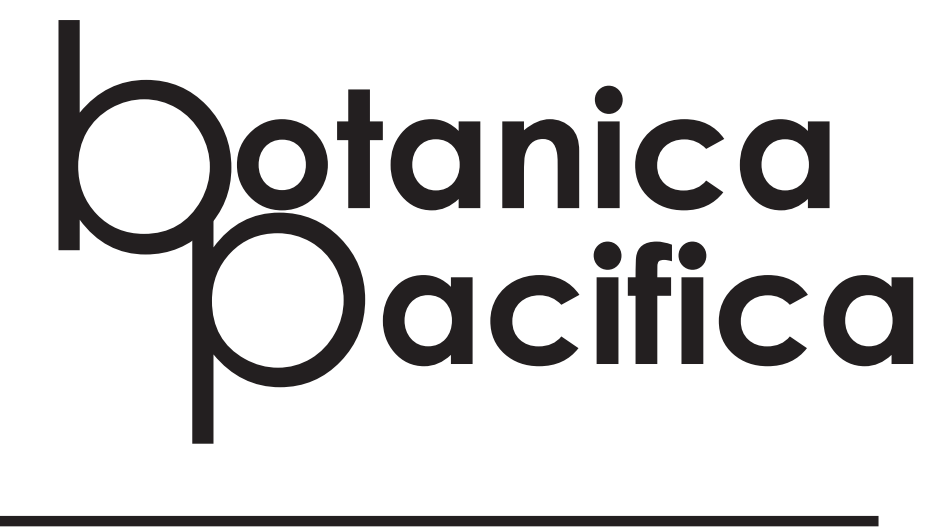

A JOURNAL OF PLANT SCIENCE
AND CONSERVATION

VOLUME 9, NO. 12020 


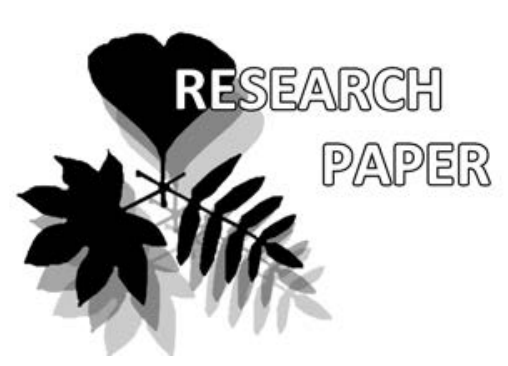

IrinaV. Gafitskaya ${ }^{1}$

e-mail: gafitskaya@biosoil.ru

Irina Yu. Orlovskava ${ }^{1}$

e-mail: irina-orlovskay@mail.ru

Olga V. Nakonechnaya*1

e-mail: markelova@biosoil.ru

Svetlana V. Nesterova ${ }^{2}$

e-mail: svnesterova@rambler.ru

${ }^{1}$ Federal Scientific Center of the East Asia Terrestrial Biodiversity FEB RAS, Vladivostok, Russia

${ }^{2}$ Botanical Garden-Institute FEB RAS,

Vladivostok, Russia

Manuscript received: 10.01.2020

Review completed: 18.04.2020

Accepted for publication: 29.04.2020

Published online: 30.04 .2020

\section{Microclonal propagation of Dasiphora fruticosa (Rosaceae)}

\author{
Irina V. Gafitskaya ${ }^{1}$, Irina Yu. Orlovskaya ${ }^{1}$, Olga V. Nakonechnaya ${ }^{1 *}$ \&
} Svetlana V. Nesterova ${ }^{2}$

\begin{abstract}
A B S T R A C T
Microclonal propagation of Dasiphora fruticosa Duham. (wild form (Df0) and cultivars 'Lovely Pink' (Df1), 'Bella Bianca' (Df2), 'Bella Sol' (Df3)) was investigated in details. Microplants were cultured on hormone-free solid 1/2 Murashige and Skoog medium. Well-formed plants with developed root system were established after 2 months of culturing. The maximum values of shoot height, number of internodes, and root mass were observed in the Df1 microplants, with a greater number of roots in the Df0 microplants. The use of half-strength medium for both growth initiation and microplant propagation allows saving reagents and reducing the cost of $D$. fruticosa microclonal multiplication in vitro. The use of ready-mixed soil with ph 5.6-6.7, and cultural vessels for growth of microplants under controlled conditions such as temperature, light and humidity made it possible to successfully adapt more than $90 \%$ of test-tube microplants to the soil conditions.
\end{abstract}

K e y w o r d s : Dasiphora fruticosa, in vitro, medicinal plant, micropropagation, cultivar, cultivation, adaptation to soil

\section{P E 3 Ю M E}

Гафицкая И.В., Ормовская И.Ю., Наконечная О.В., С.В. Нестерова. Микроклональное размножение мапчатника кустарникого (Dasiphora fruticosa, Rosaceae). Подобраны условия Аля микроклонального размножения мапчатника кустарникового (Dasiphora fruticosa (L.) Rydb.) - мекарственного и декоративного растения. В работе использованы D. fruticosa из природной популяции - Df0 и 3 декоративных сорта: «Lovely Pink» - Df1, «Bella Bianca» - Df2, «Bella Sol» - Df3. При выращивании микрорастений на безгормональной питательной среде Мурасиге и Скуга с половинной концентрацией макро- и микроэлементов через 2 месяца были получены хорошо сформированные растения с развитой корневой системой. МаксимаАьные значения высоты побегов, числа междоузмий и массы корней выявлены у растений Df1, бо́льшее число корней отмечено на растениях Df0. ЕАиный состав питательной среды Аля инициации и пролифирации позволяет экономить реактивы и делает более Аешевым микроклональное размножение $D$. fruticosa и сортов. В контролируемых $а$ абораторных условиях (температура и влажность воздуха, освещенность) более $90 \%$ пробирочных растений успешно аАаптируются к условиям почвогрунта в культуральных сосудах объемом 0,5 $\Lambda$ при использовании готовой почвенной смеси (ph 5,6-6,7).

КАючевые слова: Dasiphora fruticosa, in vitro, мекарственное растение, микроклонирование, сорт, культивирование, аАаптация к почвогрунту
The genus Dasiphora Raf. (Pentaphylloides Duham.) from the Rosaceae family is represented by three species in the Russian Far East: D. fruticosa (L.) Rydb., D. mandshurica (Maxim.) Juz., and D. davurica (Nestl.) Kom. (Kozhevnikov \& Probatova 2006). Dasiphora fruticosa grows in all regions of the Russian Far East. In Primorsky region it inhabits upper reaches of the Tayozhnaya river in Sikhote-Alin state Nature Reserve, which is the southern point of the species distribution in the Far East (Pimenova 2016). The distribution of the species includes Europe, Asia, and North America (as Pentaphylloides fruticosa in Yuzepchuk 1941, Lozina-Lozinskaya \& Zamyatnin 1954, Yakubov et al. 1996).

Some authors (Muldashev 2003, Horsák et al. 2015, Miftakhova et al. 2017) characterize D. fruticosa, as Potentilla fruticosa L., is a rare relic plant of the north-east of European part of Russia. The species is included in Red Books of Komi Republic (Taskaev 2009), Jewish Autonomous
Region (Yakubov 2006), and Republic of Bashkortostan (Muldashev \& Maslova 2011) as a rare species with declining quantity.

Dasiphora fruticosa is a deciduous shrub up to $1 \mathrm{~m}$ high, with small odd-pinnate leaves, yellow flowers $1.5-3 \mathrm{~cm}$ in diameter, single or in groups of 3 to 7 on shoot tips (Fig. 1A). The blooming period takes place from June to October, with mass flowering in August-September.

Biochemical composition and taste of the D. fruticosa is close to that of an ordinary tea (Nikolaeva et al. 2001); the shoot tips with flowers are collected and used as tea in Kamchatka and Kuril islands (Pshennikova 2002, Khramova et al. 2003). Therefore it is called a Kuril tea. Aerial parts of the plant are used in traditional medicine as antiviral agent (Mironova et al. 2008, Stalnaya 2015, Evstropov et al. 2002, Tomczyk et al. 2008, Tomczyk \& Latte 2009), and in hepatitis treatment (Nikolaeva et al. 2001). The plant possesses 
antimicrobial, immunomodulatory, and antioxidant properties (Tomczyk et al 2008, Tomczyk \& Latte 2009, Zeng et al. 2019). D. fruticosa decoctions and infusions are used for the treatment of gastrointestinal diseases in Tibetan, Indian, and Mongolian medicine (Stalnaya 2015, Zeng et al. 2019). Decoctions also normalize blood pressure, strengthen the walls of blood vessels, prevent their rupture and, thereby, heart attacks and strokes (Stalnaya 2015); the extract is used in the treatment of disbiosis in infants, as a tonic and sedative, as well as a diuretic (Khramova et al. 2003, Khramova, 2009). Dried extract can be applied in manufacture of confectionery, chewing gum, and others (Stalnaya 2015).

Dasiphora fruticosa is a melliferous and pergans plant. Mature plants inhibit soil erosion (Korzun \& Vavilova 2015). Kuril tea is an ornamental shrub and, therefore, is used in decoration of alpine hills, rocky gardens, hedges in city parks (Fig. 1A).

Studies on vegetative propagation of the Kuril tea were conducted previously, including propagation for industrial production (Korzun \& Vavilova 2015, Urusov \& Lobanova 2018). Some species of Rosaceae family such as Potentilla alba and intergeneric hybrids (Fragaria vesca $\times$ Potentilla fruticosa, Fragaria $\times$ Potentilla palustris) were propagated microclonally in vitro (Silva \& Jones 1996, Sutan et al. 2010, Tikhomirova et al. 2016 et etc.). Meanwhile, microclonal propagation method for valuable specimens of uterine plants offers great opportunities for mass plant propagation, due to a high breeding rate (up to $10^{5}-10^{6}$ specimens per year from 1 plant), possibility of all year round cultivation, little space for sterile microplant cultivation, elimination of plants from viruses, and long-term storage of microplants in tubes at low temperatures, allowing to establish a bank of genotypes of valuable species and forms (Kataeva \& Butenko 1983).

The purpose of the study was the introduction into culture in vitro and propagation of valuable medicinal and ornamental plant $D$. fruticosa and its cultivars. It was necessary to find out the conditions for successful growth and adaptation of the obtained plantlets to a soil. The study was of scientific interest and high practical value, as it represented the first stage of the shrubby Kuril tea plantations establishment in Primorsky Region. In prospect, the obtained plants could be used as a source of biologically active metabolites in pharmaceutics.

\section{MATERIAL AND METHODS}

The work on micropropagation of $D$. fruticosa plants in vitro was performed in 2015-2018 (Vladivostok). The plant sample of $D$. fruticosa (Df0) was found in collection in the Botanical Garden-Institute FEB RAS, Vladivostok. Samples of cultivars 'Lovely Pink' (Df1), 'Bella Bianca' (Df2), 'Bella Sol' (Df3) were provided from the private collection (Ussuriysk).

The shoot cuttings of 0.5 to $1.0 \mathrm{~cm}$ long with $1-2 \mathrm{ac}-$ cessory buds were used as explants. Shoot cuttings were sterilized according to a standard method (Kataeva \& Butenko 1983), using $0.1 \%$ commercial Diocide solution for 2-4 min, and placed upright in 15-mm diameter test tubes on a half-strength MS medium (Murasige and Scoog) with half-concentration of micro- and macroelements. The me- dium was autoclaved for 20 minutes at 0.8 atmospheres. The tubes with explants were further placed under luminescent light (4000 lux) at $24^{\circ} \mathrm{C}, 60-70 \%$ relative humidity, and $16 \mathrm{~h} / 8 \mathrm{~h}$ photoperiod.

Plantlets were cut, and shoot samples with one leaf were transplanted to fresh nutrient medium after 2 months. The main qualitative and quantitative characteristics of plant development during propagation in vitro are shoot length and number of internodes, and micropropagation coefficient. Characteristics of root system are important for transplanting to the ground. Morphometric parameters (are shoot length, number and length of roots) were measured weekly. We determined micropropagation coefficient as the mean number of microcuttings obtained from one regenerant plant for 1 passage (Shumikhin 2005).

We used plastic cultural containers with 0.51 volume, and soil mixture containing nitrogen $(0.2 \%)$, phosphate $(0.1 \%)$, potassium $(0.1 \%)$, water (no more than $60 \%$ ), with $\mathrm{pH}$ 5.6-6.7. The soil mixture was manufactured by ECO-AGTI Company (Korolev, Russia). We cultivated plants transmitted to soil in controlled conditions of growth chamber, described above. The data were processed using Microsoft Office Excel and STATISTICA version 13.3. The table show the arithmetic mean value of growth parameters with standard error $(n=30)$.

\section{RESULTS AND DISCUSSION}

Explant sterilization. We used $0.1 \%$ commercial Diocide solution for $4 \mathrm{~min}$ to provide qualitative surface sterilization of explants. As a result, more than $90 \%$ of viable explants (Fig. 1B) were obtained from each plant specimen, indicating that sterilizing agent and sterilization time for the Kuril tea were selected optimally.

Microclonal propagation. We obtained well developed microclones after 2 months of explants cultivation (Fig. 1C) on half-strength MS medium with half concentrations of macro- and microelements. The explants developed into microplants with 9-14 internodes (Table). This method allowed us to obtain the necessary number of microplants (about 1000 microplants) for a short period (4 months). The use of the medium with half salt concentrations allowed us to avoid the preparation of several different cultural media for initiation and proliferation, and helped to make the propagation process easier with less material and labor spendings.

Plant development during microcloning. The microplants obtained in the experiment had different morphometric characteristics (Table). Df0 explants grew actively during the third and fifth week of culturing (Fig. 2). After two months they had the smallest stem height and number of internodes, comparing with other experimental groups (Table 1). During the first week of cultivation we observed root formation in $15 \%$ of Df0 explants. After three weeks of growth $65 \%$ of explants had two or more roots. At the end of the experiment ( 2 month of culturing) we detected the maximum mean root number per Df0 plant comparing with other groups (Table 1), which probably determined high growth rates in Df0 clones during first five weeks of growth, comparing with three other experimental groups 

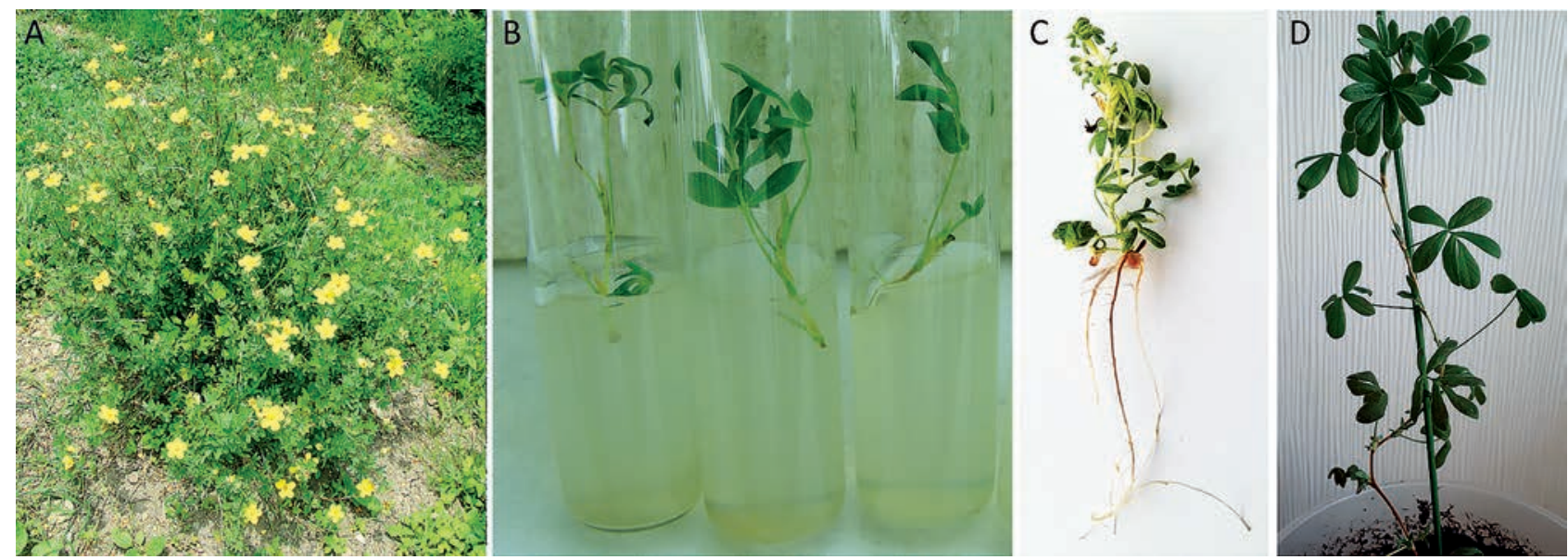

Figure 1 Dasiphora fruticosa (L.) Rydb. (Df0) in vivo (A) and in vitro (B). The microplant after two weeks of cultivation in vitro (C) and plant after adaptation to soil (D)

(Fig. 2). After five weeks, Df0-microplants ceased to grow and performed well developed plants ready to be transferred into soil.

We registered active growth of Df1-explants from fifth to eighth week of culturing (Fig. 2). Twenty percent of clones formed roots during the first week; and $60 \%$ of clones formed abundant root system five weeks later. At the end of the experiment shoot length , number of internodes and root mass of the Df1 clones were the highest comparing with other groups (Fig. 2, Table). Maximal internodes number determined the maximal propagation coefficient (12), meaning greater number of explants for further micropropagation.

Active growth of Df2 explants was observed after six weeks of cultivation (Fig. 2). Thirty-five percent of explants formed roots two weeks after start of the experiment. We registered roots on all microplants at the end of culturing; root system was formed with the main root and roots of the second and third order.

Similar to Df2 microplants, Df3 microplants displayed active growth from sixth to eighth week of cultivation (Fig. 2). The explants formed no roots during the first 2 weeks of growth. After three weeks of culturing, $55 \%$ of explants had roots. At the end of the experiment, $95 \%$ of microplants formed, in average, 2 roots per plant. The root mass was the least, comparing with other groups of microplants, because the roots were thin (Table 1). The greatest propagation coefficient in vitro (12) was achieved for Df1 cultivar ('Lovely Pink'). The lowest coefficient, 8, was provided for Df0 sample. The coefficient for Df2 ('Bella Bianca') and Df3 ('Bella Sol') was equal to 11.

The data on the cultivation features of the plant species from the Rosaceae family can be found in the literature. Thus, Ren and colleagues (2003) reported that MS culture medium supplemented with $2 \mathrm{mg} / \mathrm{L}$ 6-BAP (6-benzylaminopurine) and $0.2 \mathrm{mg} / \mathrm{L} \mathrm{NAA} \mathrm{(} \alpha$-naphthaleneacetic acid) suited the best for cultivation of tender stems of Potentilla glabra G. Lodd. The rooting of the established stems was the best on $1 / 2$ MS+NAA $0.1 \mathrm{mg} / \mathrm{L}$ cultivation medium (Ren 2003). $\mathrm{He}$ and colleagues (2006) studied micropropagation of P. potaninii Th. Wolf and used hypocotyl and cotyledon explants. They achieved the highest frequency of adventitious shoot regeneration using MS medium supplemented with $5.0 \mathrm{mg} / \mathrm{L}$ benzyladenine (BA) and $1.0 \mathrm{mg} / \mathrm{L} \mathrm{NAA}$ ). The reproduction effect of the $P$. fruiticosa 'Gold Drop' explants was the best when the concentration of 6-BAP was $2.0 \mathrm{mg} / \mathrm{L}$. The medium MS+2.0 mg/L 6-BAP +0.6 mg/L $\mathrm{NAA}+0.2 \mathrm{mg} / \mathrm{L} \mathrm{K}$ (kinetin) was defined as the optimum for the P. fruiticosa 'Gold Drop' explants proliferation. And the optimal rooting medium for the same species was MS+0.1 mg/L NAA + $1.0 \mathrm{mg} / \mathrm{L} \mathrm{KT} \mathrm{(Ma} \mathrm{et} \mathrm{al.} \mathrm{2009).} \mathrm{The}$ optimum concentration of phytohormones for the P. alba $\mathrm{L}$. in vitro micropropagation was $1.0 \mu \mathrm{M} 6-\mathrm{BAP}+0.5 \mu \mathrm{M}$ IBA (indolebutyric acid) $+0.05 \mu \mathrm{M}$ GA (gibberellic acid) (Tikho-

Table 1. Morphometric parameters of Dasiphora fruticosa microplants. Df0 - Dasiphora fruticosa wild species, Df1 - D. fruticosa cultivar 'Lovely Pink', Df2 - D. fruticosa cultivar 'Bella Bianca', Df3 - D. fruticosa cultivar 'Bella Sol'.

\begin{tabular}{|c|c|c|c|c|}
\hline \multirow{2}{*}{ Parameters } & \multicolumn{4}{|c|}{ Dasiphora fruticosa } \\
\hline & Df0 & Df1 & Df2 & Df3 \\
\hline Plant height, mm & $28.90 \pm 2.50$ & $33.21 \pm 3.98$ & $30.35 \pm 5.94$ & $30.95 \pm 3.79$ \\
\hline Number of internodes & $9.40 \pm 0.81$ & $13.80 \pm 0.2$ & $12.40 \pm 0.74$ & $12.40 \pm 0.51$ \\
\hline Number of roots & $3.95 \pm 0.36$ & $2.40 \pm 0.30$ & $1.94 \pm 0.25$ & $2.16 \pm 0.33$ \\
\hline Length of $1^{\text {st }}$ root, $\mathrm{mm}$ & $41.60 \pm 3.78$ & $63.87 \pm 3.59$ & $56.72 \pm 4.69$ & $54.49 \pm 4.45$ \\
\hline Length of $2^{\text {nd }}$ root, $\mathrm{mm}$ & $23.76 \pm 2.36$ & $30.55 \pm 6.24$ & $22.38 \pm 4.60$ & $22.92 \pm 5.76$ \\
\hline Length of $3^{\mathrm{d}}$ root, $\mathrm{mm}$ & $17.32 \pm 1.77$ & $17.65 \pm 4.60$ & $6.96 \pm 2.17$ & $9.33 \pm 4.02$ \\
\hline Length of $4^{\text {th }}$ root, $\mathrm{mm}$ & $11.19 \pm 2.09$ & $6.93 \pm 3.11$ & $2.22 \pm 2.22$ & $2.62 \pm 1.53$ \\
\hline Fresh weight of roots, $\mathrm{mg}$ & $0.03 \pm 0.00$ & $0.04 \pm 0.01$ & $0.03 \pm 0.00$ & $0.02 \pm 0.00$ \\
\hline
\end{tabular}




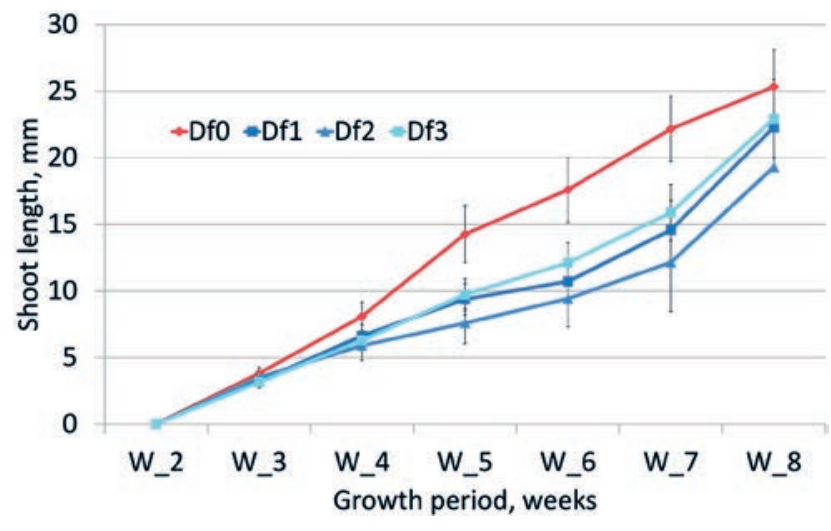

Figure 2 Growth dynamics of Dasiphora fruticosa cultivars during 8 weeks

mirova et al. 2016). Production of P. fulgens Wall. ex Hook. plantlets with better rate of shoot multiplication and elongation obtained on MS medium supplemented with $1 \mathrm{mg} / \mathrm{L} \mathrm{K}$ alone or combined with $1 \mathrm{mg} / \mathrm{L} \mathrm{NAA} \mathrm{(Sambyal} \mathrm{et} \mathrm{al.} \mathrm{2006).}$

It is interesting to note that the in vitro propagation coefficient for $P$. alba (average fold multiplication) was 9.3 (Tikhomirova et al. 2016) and 11.6 for P. fulgens (Sambyal et al. 2006). P. alba and P. fulgens are herbaceous plants. Our study with $D$. fruticosa also revealed high propagation coefficient for the representative of the Rosaceae family with different growth form - a shrub. Herbaceous plants are often characterized with a high propagation coefficient, but for $P$. alba grown on a hormone-free medium it was equal to 1 (Tikhomirova et al. 2016). It is likely, that different species of Rosaceae family have different breeding potential. In some cases, the use of hormones was necessary to increase the propagation coefficient. The use of hormones for $D$. fruticosa was unnecessary, as it displayed high propagation coefficient on a hormone-free medium, and the resulting plants were not overloaded with hormones.

Planting $\boldsymbol{D}$. fruticosa into soil. Adaptation of test tube microplants to soil conditions is a complex process, therefore, conditions with gradual air and substrate moisture regulation in cultural vessels were conducted when transferring the microplants into soil. Substrate quality is an important factor of microplant adaptation. The use of a ready for use soil with composition optimal for our microplants allowed us to make the transfer into soil gentle and effective. In result, microplant survival in the soil was more than $90 \%$. Plants grew actively after the transfer, and formed shrubs up to 15 $\mathrm{cm}$ tall (Fig. 1D). Time period from planting the explants on a medium to the development of plants with good fitness was equal to 4 months. By this time, 350 plants were planted on experimental plot on the open ground.

\section{CONCLUSIONS}

Thus, sterilization of explants with $0.1 \%$ commercial Diocide solution during 4 minutes allowed us to obtain more than $90 \%$ of sterile well-growing microplants, when introducing the Kuril tea, D. fruticosa, into culture. The explants started to grow actively on nutrient medium from the third (Df1) to the sixth (Df2, Df3, Df4) weeks of culturing. Despite some distinction between microplants of different cultivars (shoot length, internodes number, root number and fresh weight), all of them transformed into well-developed plants with abundant root system and strong shoots within 2 months of cultivation on hormone-free half-strength MS medium. The unified composition of medium for both growth initiation and proliferation, applied in this work, allows decreasing material costs and reagents consumption for microclonal propagation of $D$. fruticosa and cultivars. Application of a ready-made soil mixture for plant growing in controlled conditions (temperature, illuminance, and air humidity) led to a successful adaptation of more than $90 \%$ of test tube microplants to soil conditions.

\section{ACKNOWLEDGEMENTS}

The authors are grateful to Mikhail Victorovich Mikhalin for provided D. fruticosa cultivars ('Lovely Pink', 'Bella Bianca', 'Bella Sol') for microclonal propagation.

\section{LITERATURE CITED}

Evstropov, A.N., L.G. Burova, O.R.Greck, L.N.Zakharova \& T.A. Volkhonskay 2002. The employment of polyphenol complexes extracted from Penthaphylloides fruticosa (L.) O. Scwarz for prophylactic of Coxsackie-virus infection. Bulletin of Siberian Medicine 4:27-31 (in Russian with English summary). [Евстропов А.Н., Бурова А.Г., Грек O.P., Захарова А.Н., Волхонская Т.А. 2002. Применение полифенольного комплекса, экстрагированного из пятилистника кустарникового (Penthaphylloides fruticosa (L.) O. Scwarz), А^я профилактики Коксаки-вирусной инфекции // Бюлметень сибирской медицины. Т. 4. C. 27-31.

He, W.T., S.W. Hou \& C.Y. Wang 2006. An efficient in vitro method for mass propagation of Potentilia potanii Wolf. In Vitro Cellular \& Developmental Biology - Plant 42(5):415-417.

Horsák, M., M. Chytrý, P. Hájková, M. Hájek, J. Danihelka, V. Horsáková, N. Ermakov, D.A. German, M. Koči, P. Lustyk, J.C. Nekola, Z. Preislerová \& M. Valachovič 2015. European glacial relict snails and plants: environmental context of their modern refugial occurrence in southern Siberia. Boreas 44(4):638-657.

Kataeva, N.V. \& R.G. Butenko 1983. Clonal micropropagation of plants. Nauka, Moscow, 97 pp. (in Russian). [Катаева Н.В., Бутенко Р.Г. 1983. КАональное микроразмножение растений. М.: Наука. 97 с.].

Khramova, E.P., K.P. Koutzenogij, G.A. Kovalskaya \& O.V. Chankina 2003. Trace elements in different Pentaphylloides fruticosa ecotypes. Journal of Trace and Microprobe Techniques 21(1):133-145.

Khramova, E.P. 2009. Variability of flavonoid content of Pentaphylloides fruticosa (L.) O. Schwarz under culture conditions. In: New advances in chemistry and chemical technology of plant materials: materials of the IV All-Russian Conference (N.G. Bazarnova \& V.I. Markin, eds), pp. 82-84, Izdatel'stvo Altaiskogo Universiteta, Barnaul (in Russian). [Храмова Е.П. 2009. Изменчивость содержания фмавоноилов Pentaphylloides fruticosa (L.) O. Schwarz в условиях культуры // Новые Аостижения в химии и химической технологии растительного сырья: материалы IV Всероссийской конференции / поА реА. Н.Г. Базарновой и В.И. Маркина. Барнаул: ИзА-во Алт. ун-та, С. 82-84].

Korzun, B.V. \& L.V. Vavilova 2015. Technology of cultivation of the silverweed shrubby (Kuril tea) Potentilla L. in the foothill zone of the republic of Adyghea. Novye technologii 
3:1-9 (in Russian with English summary). [Корзун Б.В., Вавилова А.В. 2015. Технология возделывания мапчатки кустарниковой (курильского чая) Potentilla L. в предгорной зоне Респуб̆лики Адыгея // Новые технологии. №. 3. С. 1-9].

Kozhevnikov, A.E. \& N.S. Probatova (eds) 2006. Flora of the Russian Far East. Addenda and corrigenda to "Vascularplants of the Soviet Far East” Vol.1-8 (1985-1996). 2006. Dal'nauka, Vladivostok, 456 pp. (in Russian). [ФАора российского Аальнего Востока: Аополнения и изменения к изданию «Сосудистые растения советского Аальнего Востока» Т. 1-8 (1985-1996). 2006 / под реА. А.Е. Кожевникова и Н.С. Пробатовой. ВАадивосток: Аальнаука. 456 c.].

Lozina-Lozinskaya, A.S. \& B.N. Zamyatnin 1954. The family Rosaceae Juss. In: Trees and shrubs of the USSR, (S.Ya. Sokolov, ed.), pp. 256-812, Izdatel'stvo AN SSSR, Moscow, Leningrad (in Russian). [Аозина-Аозинская A.C., Замятнин Б.Н. 1954. Сем. Розоцветные - Rosaceae Juss. // Аеревья и кустарники СССР. Покрытосеменные: Семейства троходендровые - розоцветные / пол ред. С.Я. Соколова. М., А.: Иза-во АН СССР. Т. 3. C. 256-812].

Ma, Y., K. Li, X. Tian \& J. Li 2009. Culture in vitro and rapid propagation system with Potentilla fruiticosa 'Gold Drop'. Bulletin of Botanical Research 29(5):623-627.

Miftakhova, S.A., O.V. Skrotskaya \& K.S. Zainullina 2017. Biology of the rare species of Pentaphylloides fruticosa (Rosaceae) in culture in the North. Izvestiya Komi Nauchnogo Tsentra UrO RAN 2(30):30-36 (in Russian with English summary). [Мифтахова С.А., Скроцкая О.В., ЗайнулАина К.С. 2017. Биология реАКого виАа - курильского чая (Pentaphylloides fruticosa) - в культуре на Севере // Известия Коми научного центра УРО РАН. №. 2, вып. 30. С. 30-36].

Mironova, G.D., M.I. Shigaeva, N.V. Belosludtseva, E.N. Gritsenko, K.N. Belosludtsev, E.L. Germanova \& L.D. Lukyanova 2008. Effect of several flavonoid-containing plant preparations on activity of mitochondrial ATPdependent potassium channel. Bulletin of Experimental Biology and Medicine 146(2):229-233.

Muldashev, A.A. 2003. Floristic records in Bashkortostan (Russia). Botanicheskii Zhurnal 88(1):120-129 (in Russian with English summary). [Мулдашев А.А. 2003. Фцористические находки в Башкортостане (Россия) // Ботанический журнал. Т. 88, №1. С. 120-129].

Muldashev, A.A. \& N.V. Maslova 2011. Pentaphylloides fruticosa (L.) O. Schwarz. In: The Red Book of the Republic of Bashkortostan. Plants and Fungi (B.M. Mirkin, ed.), p. 134, MediaPrint, Ufa (in Russian). [Мулдашев А.А., Маслова Н.В. 2011. Курильский чай кустарниковый Pentaphylloides fruticosa (L.) O. Schwarz. // Красная книга Респуб̆лики Башкортостан: в 2 т. Т. 1: Растения и грибы / под ред. Миркина Б.М. Уфа: МедиаПринт. С. 134].

Murashige, T. \& F. Skoog 1962. A revised medium for rapid growth and bio-assays with tobacco tissue cultures. Physiologia Plantarum 15(3):473-497.

Nikolaeva, I.G., V.B. Khobrakova \& M.M. Ar'yaeva 2001. Medicinal plants used as Tibetan medicine. The shrubby cinquefoil (Pentaphylloides fruticosa (L.) O. Schwary), Izdatel'stvo BNC SO RAN, Ulan-Ude, 110 pp. (in Russian). [Николаева И.Г., Хобракова В.Б., Арьяева М.М. 2001. Аекарственные растения тибетской медицины. ПятиАистник кустарниковый (курильский чай кустарниковый). УАан-У Аэ: ИзА-во БНЦ СО РАН. 110 с.].
Pimenova E.A. (ed.) 2016. Plants, fungi and lichens of the Sikhote-Alin Reserve. Dalnauka, Vladivostok, 557 pp. (in Russian). Растения, грибы и мишайники Сихотэ-А^инского заповедника / под реА. Е.А. Пименовой. ВАаАивосток: Аальнаука. 556 с.].

Pshennikova, L.M. 2002. New woody plants for the south of Primorsky Krai. Dal'nauka, Vladivostok, 48 pp. (in Russian). [Пшенникова А.M. 2002. Новые Аревесные растения А^я юга Приморского края. ВАадивосток: Аальнаука. 48 c.].

Ren, J. 2003. In vitro propagation of Potentilla glabra. Journal of Gansu Agricultural University (Gansu nongye daxue xuebao) 38(2):231-233.

Sambyal, M., A. Dogra, S. Koul, \& A. Ahuja 2006. Rapid in vitro propagation of Potentilla fulgens Wall - A himalayan alpine herb of medicinal value. Journal of plant biochemistry and biotechnology 15(2):143-145.

Shumikhin S.A. 2005. The optimisation of the growing medium for clonal propagation of Dablias $\times$ cultorum in vitro. Vestnike Permskogo Universiteta. Ser. Biologiya 6: 59-63 (in Russian with English summary). ШШумихин C.A. 2005. Оптимизация питательной среды при микроклональном размножении георгины культурной // Вестник Пермского университета. Серия: Биология. Вып. 6. С. 59-63].

Silva, T. \& J.K. Jones 1996. In vitro production and propagation of Fragaria vesca $\times$ Potentilla fruticosa hybrids. Plant cell, tissue and organ culture 46(1):51-58.

Stal'naya, M.I. Prospects of the use of functional products from shrubby Kuril tea. Innovatsionnaya Nauka 1-2:102103 (in Russian). [Стальная М.И. 2015. Перспективы использования функциональных продуктов из курильского чая кустарникового // Инновационная наука. № 1-2. С. 102-103].

Sutan, A.N., A.U.R.E.L. Popescu \& V. Isac, 2010. In vitro culture medium and explant type effect on callogenesis and shoot regeneration in two genotypes of ornamental strawberry. Romanian biotechnological letters 15(2):12-18.

Taskaev, A.I. (ed.) 2009. The Red Book of the Komi Republic Komi Scientific Center UrO RAN, Syktyvkar, 791 pp., (in Russian). [Красная книга Республики Коми / поА ред. Таскаева А.И. Сыктывкар: Коми НЦ УрО РАН, 2009. 791 c.].

Tikhomirova, L.I., A.A. Kechaykin, A.I. Shmakov \& O.V. Aleksandrova, 2016. An effective way to carry out mass in vitro propagation of Potentilla alba L. Biological Bulletin of Bogdan Chmelnitskiy Melitopol State Pedagogical University 6:433-444.

Tomczyk, M. \& K.P. Latté 2009. Potentilla - a review of its phytochemical and pharmacological profile. Journal of Ethnopharmacology 122(2):184-204.

Tomczyk, M., K. Leszczyńska \& P. Jakoniuk 2008. Antimicrobial activity of Potentilla species. Fitoterapia 79(7-8): 592-594.

Urusov, V.M. \& I.I. Lobanova 2018. Trees, shrubs and lianas of Primorsky Krai. Pacific Geographical Institute, Vladivostok, 475 рр. (in Russian). [Урусов В.М., Аобанова И.И. 2018. Аеревья, кустарники и мианы Приморского края. ВАаАивосток: ТИГ АВО РАН. 475 с.].

Yakubov, V.V. 2006. Pentaphylloides fruticosa (L.) O. Schwarz. In: Red Data Book of the Jewish Autonomous Region Rare and Endangered Species of Plants and Mushrooms (T.A. Rubtsova, ed.), p. 128, Arta, Novosibirsk (in Russian with English 
abstract). [Якубов В.В. 2006. Пятилисточник кустарниковый Pentaphylloides fruticosa (L.) O. Schwarz // Kрасная книга Еврейской автономной области. Редкие и находящиеся поА угрозой исчезновения виды сосуАистых растений / под реА. Т.А. Рубцовой. Новосибирск: Арта. С. 128].

Yakubov, V.V., V.A. Nedoluzhko, I.A. Shantser, V.N. Tikhomirov \& S.D. Rumyantsev 1996. Rosaceae. In: Vascular plants of the soviet Far East (S.S. Kharkevych, ed.), 383 pp. Nauka, Saint-Petersburg. (in Russian) [Якубов B.В., Недолужко В.А., Шанцер И.А., Тихомиров В.Н., Румянцев С.А 1996. Розовые - Rosaceae // Сосудистые растения советского Аальнего Востока. Т. 8. СПб.: Наука. 383 с.]
Yuzepchuk, S.V. 1941. Dasiphora Raf. In: Flora of the USSR (V.L. Komarov, ed.), 3:68-73. Izdatel'stvo AN USSR, Moscow, Leningrad (in Russian). [Юзепчук C.B. Куримьский чай - Dasiphora Raf // ФАора СССР. Т. 10. М.; А.: Иза-во АН СССР, 1941. С. 68-73].

Zeng, Y., Y.X. Sun, X.H. Meng, T. Yu, H.T. Zhu \& Y.J. Zhang 2019. A new methylene bisflavan-3-ol from the branches and leaves of Potentilla fruticosa. Natural Product Research 19:1-8. 